\title{
PELATIHAN PENYUSUNAN RENCANA PELAKSANAAN PEMBELAJA- RAN HARIAN BERBASIS KURIKULUM 2013 BAGI GURU-GURU PAUD
}

\author{
Rohita $^{1^{*}}$, Nila Fitria ${ }^{1}$ \\ ${ }^{I}$ Program studi Pendidikan Guru Pendidikan Anak Usia Dini, Fakultas Psikologi dan Pendidikan, \\ Universitas Al Azhar Indonesia, Jalan Sisingamangaraja, Kompleks Masjid Agung Al Azhar, Ke- \\ bayoran Baru, Jakarta Selatan 12110
}

Email Penulis Korespondensi: rohita@uai.ac.id

\begin{abstract}
Abstrak
Hasil penelitian mengenai Pengetahuan, Pemahaman Dan Penerapan Kurikulum 2013 Guru-Guru TK yang dilakukan oleh Rohita dan Fitria (2017) diketahui bahwa tingkat pengetahuan guru mengenai kurikulum 2013, sebesar 95.8\%,dan tingkat pemahaman sebesar 21\%. Namun, 91,7\% responden mengalami kesulitan dalam memahami kurikulum 2013 serta kesulitan dalam menggunakan kurikulum 2013. Sementara dalam penyusunan Rencana Pelaksanaan Pembelajaran Harian (RPPH) berbasis kurikulum 2013, 58.40\% guru belum menggunakan kurikulum 2013 dalam menyusun perencanaan pembelajaran, serta 79.20\% merasa kesulitan dalam menyusun RPPH menggunakan kurikulum 2013. Tujuan dari kegiatan ini adalah meningkatkan pemahaman dan kemampuan guru PAUD dalam menyusun RPPH berbasis Kurikulum 2013. Metode kegiatan yang dilaksanakan berupa pemberian pre tes, penyajian materi, simulasi pelaksanaan pembelajaran sesuai RPPH yang telah disusun sebelumnya, dan pemberian pos tes. Subjek penelitian adalah guru-guru PAUD di wilayah Kecamatan Tanah Abang Jakarta Pusat. Hasil kegiatan pelatihan menunjukkan adanya peningkatan pemahaman peserta yaitu sebesar 25\% yang diikuti dengan peningkatan kemampuan peserta dalam menyusun RPPH, yaitu sebesar $37.50 \%$ dibandingkan sebelum pelatihan. Hal ini disebabkan salah satunya karena metode pelatihan yang dilakukan dengan cara penyampaian materi, workshop dan simulasi. Namun dalam pelaksanaan simulasi, guru-guru PAUD belum mampu menghadirkan media sesungguhnya atau bentuk tiga dimensi dalam proses penyampaian materi. Sementara media yang digunakan masih lebih banyak pemakaian paper and pencil. Adapun simpulan dari kegiatan ini adalah terdapat peningkatan pemahaman guru PAUD dalam menyusun RPPH Berbasis Kurikulum sebesar $25 \%$ dan peningkatan kemampuan guru PAUD dalam menyusun RPPH Berbasis Kurikulum sebesar $37.50 \%$.
\end{abstract}

Kata Kunci : Guru PAUD, Kurikulum 2013, Rencana Pelaksanaan Pembelajaran Harian

\begin{abstract}
The results of the study on Knowledge, Understanding and Application of 2013 Curriculum for Kindergarten Teachers conducted by Rohita and Fitria (2017) revealed that the level of teacher knowledge about the 2013 curriculum was $95.8 \%$, and the level of understanding was $21 \%$. However, $91.7 \%$ of respondents experienced difficulties in understanding the 2013 curriculum and difficulties in using the 2013 curriculum. While in the preparation of the 2013 curriculum-based Daily Learning Plan (RPPH), $58.40 \%$ of teachers did not use the 2013 curriculum in preparing learning plans, and $79.20 \%$ felt the difficulty in preparing RPPH using the 2013 curriculum. The purpose of this activity was to improve the understanding and ability of PAUD teachers in compiling RPPH based on 2013 curriculum. The method of the activities carried out was giving pre-tests, presenting material, implementing simulation according to RPPH previously prepared, and giving test post. The research subjects were PAUD teachers in the Tanah Abang District, Central Jakarta. The results of the training activities showed an increase in participants' understanding of $25 \%$ followed by an increase in the ability of participants to
\end{abstract}


prepare RPPH, which was $37.50 \%$ compared to before training. This is due to one of them because the training method is carried out by delivering material, workshops and simulations. But in the implementation of simulations, PAUD teachers have not been able to present real media or three-dimensional forms in the process of delivering material. While the media used is still using paper and pencil. The conclusion of this activity is that there is an increase in the understanding of PAUD teachers in compiling curriculum-based RPPH by $25 \%$ and an increase in the ability of PAUD teachers to develop curriculum-based RPPH of $37.50 \%$.

Keywords: 2013 Curriculum, Daily Learning Implementation Plan, PAUD Teachers

\section{PENDAhUluan}

Guru merupakan salah satu profesi yang dalam pelaksanaan profesinya membutuhkan penguasaan dalam berbagai kompetensi. Salah satu kompetensi yang harus dikuasai adalah kompetensi pedagogik, yang diantara inidikatornya adalah kemampuan merancang pembelajaran. Rancangan pembelajaran dalam bidang pendidikan anak usia dini, dinamakan dengan rencana pembelajaran, baik rencana pembelajaran mingguan maupun rencana pembelajaran harian.

Berdasarkan hasil wawancara dengan pendidik sekaligus pengelola BKB PAUD Flamboyan, yang terletak di wilayah Jakarta Pusat, diketahui bahwa guru-guru di BKB PAUD Flamboyan juga PAUD-PAUD lain di sekitarnya belum menyusun perencanaan pembelajaran sebagaimana mestinya, terlebih jika dikaitkan dengan kurikulum 2013. Kenyataan tersebut dibuktikan pula dengan hasil observasi yang dalam pembelajarannya, guru PAUD di lembaga tersebut, melakukan pembelajaran terkadang tidak sesuai dengan perencanaan pembelajaran. Berdasarkan analisis situasi yang telah diuraikan, maka dapat diketahui bahwa masalah yang dihadapi guru di BKB PAUD Flamboyan adalah masalah dalam bidang pendidikan, yaitu dalam hal kurangnya pemahaman dan kemampuan guru dalam menyusun perencanaan pembelajaran yang sesuai dengan kurikulum yang berlaku yaitu kurikulum 2013.

Permasalahan dalam penyusunan rencana pembelajaran harian tidak hanya dialami oleh guru-guru PAUD, khususnya Guru PAUD di wilayah Jakarta Pusat, tetapi juga dialami oleh guru TK. Guru PAUD dan Guru TK memang memiliki perbedaan dalam hal jalur pemberian layanan pendidikan, dimana Guru PAUD memberikan layanan pendidikan pada jalur non formal, sementara guru TK memberikan layanan pendidikan pada jalur formal. Akan tetapi baik guru PAUD maupun guru TK memiliki kewajiban yang sama dalam hal penguasaan kompetensi, termasuk kompetensi Pedagogik. Hal lain yang juga tidak dapat dibedakan adalah kenyataan bahwa meskipun nama lembaganya PAUD, tetapi pihak sekolah juga memberikan layanan pendidikan untuk anak usia TK yaitu usia $4-6$ tahun.

Hasil penelitian mengenai pengetahuan, pemahaman dan penerapan Kurikulum 2013 guru-guru TK yang dilakukan oleh Rohita, Fitria, dan Haryadi (2018: 648), menunjukkan data yang disajikan dalam bentuk diagram pie berikut.

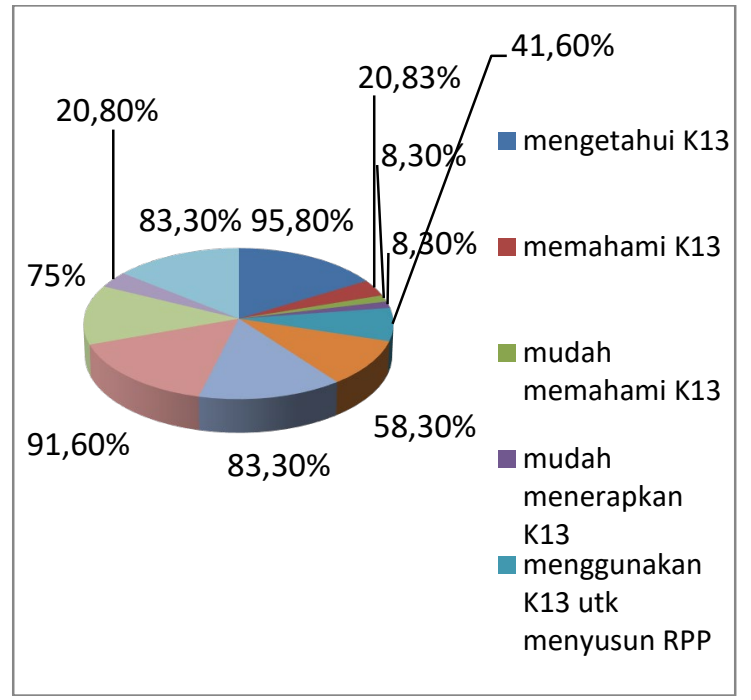

Gambar 1. Diagram Persentase Tingkat Pengetahuan, Pemahaman dan Penerapan K13

Berdasarkan diagram pada gambar 1 dapat diketahui bahwa terdapat dua point penting terkait pengetahuan guru tentang kurikulum 2013 dan terkait pemahaman guru mengenai kurikulum 2013 serta penerapannya. Terkait pengetahuan guru mengenai kurikulum 2013 diperoleh data sebagai berikut: dari 24 orang guru, $95.8 \%$ telah memiliki pengetahuan akan kurikulum 2013; 20.83\% telah memahami kurikulum 2013; 8.30\% tidak ada kesulitan 
dalam memahami kurikulum 2013; 8.30\% tidak ada kesulitan dalam menerapkan atau menggunakan kurikulum 2013.

Sementara terkait pemahaman dan kemampuan guru menerapkan kurikulum 2013 diperoleh data sebagai berikut: dari 24 orang guru, $41.60 \%$ telah menggunakan kurikulum 2013 dalam menyusun perencanaan pembelajaran; $58.30 \%$ menggunakan kurikulum 2013 sebagai pedoman dalam pembelajaran; $83.30 \%$ membuat RPPM berbasis K13 setiap minggu; 91,60\% membuat RPPH berdasarkan RPPM; 75\% membuat RPPH setiap hari; $20.80 \%$ mudah menyusun RPPH; dan $83.30 \%$ melakukan pembelajaran sesuai RPPH

Berdasarkan data-data tersebut, dapat dikatakan bahwa tingkat pengetahuan guru mengenai kurikulum 2013 sangat tinggi yaitu $95.8 \%$ dan diiringi dengan pemahaman yang cukup tinggi yaitu $21 \%$. Namun, $91,7 \%$ nampak mengalami kesulitan dalam upaya memahami kurikulum 2013 serta kesulitan dalam menerapkan atau menggunakan kurikulum 2013. Sementara dalam penyusunan RPPH berbasis kurikulum 2013, dapat dikatakan bahwa terdapat $58.40 \%$ guru yang belum menggunakan kurikulum 2013 dalam menyusun perencanaan pembelajaran. Kemudian, berdasarkan data pula diketahui bahwa guru telah menyusun RPPM dan RPPH serta melaksanakan pembelajaran sesuai dengan RPPH yang telah disusunnya, namun sebanyak $79.20 \%$ mengakui bahwa mereka masih mengalami kesulitan dalam menyusun RPPH menggunakan kurikulum 2013.

Salah satu penelitian juga menemukan kesulitan yang dihadapi guru terkait dengan kurikulum. Ntumi (2016: 54) menuliskan bahwa:

The key findings of the study revealed that pre-school teachers are faced with a lot of challenges in implementing the early childhood curriculum. A notable one among them are that most pre-school teachers do not understand the early childhood curriculum, pre-school teachers do not have enough teaching and learning materials to help them implement the Early childhood curriculum, parents do not involve themselves in their wards education therefore it makes it difficult for pre-school to do the work alone. It was also revealed that teachers, teaching and learning materials are the main factors that influence the implementation of the early childhood curriculum"

Kesulitan lain yang dihadapi guru juga ditemukan oleh Metina (2013). Ia menuliskan bahwa:

"teachers do not determine appropriate topics for students' level and appropriate criteria for topics and have insufficient knowledge about how prepared rubrics. Besides, it is seen that teachers encounter some difficulties such as crowded classroom, insufficient time for assessment, insufficient learning environment and technological opportunity and they do not do objective assessment. One of the most issues encountered teachers is not determinate topic of appropriate performance task to students' levels. In consequence of investigating performance task developed by teachers, it was seen that teachers were not specify to content of performance task. Similar result was seen observation activities in the classroom."

Berdasarkan pemaparan di atas maka tujuan dari kegiatan pengabdian kepada masyarakat ini adalah untuk meningkatkan pemahaman dan kemampuan guru-guru, khususnya guru PAUD dalam memahami kurikulum 2013 khususnya, untuk meningkatkan kemampuan dalam menyusun Rencana Pelaksanaan Pembelajaran Harian berbasis Kurikulum 2013.

\section{Kurikulum PAUD}

Di dalam UU No. 20 Tahun 2003 disebutkan bahwa yang dimaksud dengan Kurikulum adalah seperangkat rencana \& sebuah pengaturan berkaitan dengan tujuan, isi, bahan ajar \& cara yang digunakan sebagai pedoman dalam penyelenggaraan kegiatan pembelajaran untuk mencapai sebuah tujuan pendidikan nasional.

Salah satu hal yang perlu diperhatikan pendidik terkait dengan kurikulum 2013 adalah dalam membuat persiapan pembelajaran yang harus dapat disesuaikan dengan kondisi sekolah, karakteristik dan kebutuhan peserta didik, serta disesuaikan dengan lingkungan anak. Melalui perencanaan pembelajaran yang baik, pendidik dapat melaksanakan pembelajaran dengan mudah dan terarah yang dapat membuat anak didik lebih mudah menyerap informasi yang pendidik berikan.

Selain perlunya memahami kurikulum, pendidik juga harus terus menerus memperbaiki dirinya, pengetahuannya, serta keterampilannya. Hal tersebut sesuai dengan apa yang dituliskan 
Selvi, bahwa Teachers need to improve knowledge and skills to enhance, improve and explore their teaching practices.

Saat ini kurikulum yang berlaku untuk anak usia dini adalah kurikulum 2013. Berdasarkan Peraturan Menteri Pendidikan dan Kebudayaan Republik Indonesia Nomor 146 Tahun 2014 tentang Kurikulum 2013 Pendidikan Anak Usia Dini, pasal 3 disebutkan bahwa Pendidikan Anak Usia Dini mengacu pada Standar Nasional Pendidikan Anak Usia Dini. Kurikulum tersebut terdiri atas, salah satunya, Struktur Kurikulum. Struktur Kurikulum merupakan pengorganisasian Struktur Kurikulum merupakan pengorganisasian muatan kurikulum, Kompetensi Inti, kompetensi Dasar, dan lama belajar.

Kompetensi inti PAUD merupakan gambaran pencapaian Standar tingkat Pencapaian Perkembangan anak pada akhir layanan PAUD usia 6 tahun, yang dirumuskan secara terpadu dalam bentuk: Kompetensi Inti Sikap Spiritual (KI-1); Kompetensi Inti Sikap Sosial (KI-2); Kompetensi Inti Pengetahuan (KI-3); dan Kompetensi Inti Keterampilan (KI4). Kompetensi Dasar merupakan tingkat kemampuan dalam konteks muatan pembelajaran, tema pembelajaran, dan pengalaman belajar yang mengacu pada Kompetensi Inti, yang terdiri atas: Kompetensi Dasar sikap spiritual; Kompetensi Dasar sikap sosial; Kompetensi Dasar Pengetahuan; dan Kompetensi Dasar Keterampilan.

Struktur kurikulum PAUD memuat programprogram pengembangan yang mencakup: a.nilai agama dan moral; b.fisik-motorik; c.kognitif; d.bahasa; e.sosial-emosional; dan f.seni. Program pengembangan nilai agama dan moral mencakup perwujudan suasana belajar untuk berkembangnya perilaku baik yang bersumber dari nilai agama dan moral serta bersumber dari kehidupan bermasyarakat dalam konteks bermain. Program pengembangan fisik-motorik mencakup perwujudan suasana untuk berkembangnya kematangan kinestetik dalam konteks bermain. Program pengembangan kognitif mencakup perwujudan suasana untukberkembangnya kematangan proses berfikir dalam konteks bermain.

Program pengembangan mencakup perwujudan suasana untuk berkembangnya kematangan bahasa dalam konteks bermain.
Program pengembangan sosial-emosional mencakup perwujudan suasana untuk berkembangnya kepekaan, sikap, dan keterampilan sosial serta kematangan emosi dalam konteks bermain.Program pengembangan seni mencakup perwujudan suasana untuk berkembangnya eksplorasi, ekspresi, dan apresiasi seni dalam konteks bermain. Program pengembangan diberikan melalui rangsangan pendidikan yang dilakukan oleh pendidik dalam kegiatan belajar melalui suasana bermain. Belajar melalui bermain merupakan kegiatan belajar anak yang dilakukan melalui suasana dan aneka kegiatan bermain.

Terkait dengan waktu atau lamanya belajar, di dalam Permendikbud nomor 146 tahun 2014 diketahui bahwa untuk anak usia 4-6 tahun lama belajar yang harus ditempuh paling sedikit adalah 900 menit dalam 1 minggu atau dengan perkataan lain, 3 jam dalam satu hari.

\section{Karakteristik Kurikulum 2013 Pendidikan Anak Usia Dini}

Kurikulum 2013 Pendidikan Anak Usia Dini dirancang dengan karakteristik sebagai berikut: 1). mengoptimalkan perkembangan anak yang meliputi: a). aspek nilai agama dan moral; b). fisik-motorik; c). Kognitif; d).Bahasa; e). sosial emosional; dan f). seni yang tercermin dalam keseimbangan kompetensi sikap, pengetahun, dan keterampilan; 2). menggunakan pembelajaran tematik dengan pendekatan saintifik dalam pemberian rangsangan pendidikan; 3). Menggunakan penilaian autentik dalam memantau perkembangan anak; dan 4). memberdayakan peran orangtua dalam proses pembelajaran Adapun tujuan Kurikulum 2013 Pendidikan Anak Usia Dini Kurikulum 2013 adalah untuk mendorong berkembangnya potensi anak agar memiliki kesiapan untuk menempuh pendidikan selanjutnya.

Hal senada dikemukakan Olibie (2013), yaitu:

The reforms have given rise to a range of emergent curriculum trends which have significant implications on how teachers should teach. Nations must continuously develop curriculum to meet the demands of an ever-changing society, the needs of the children, and the criteria for what students need to learn and do to attain successful outcomes. In other words, the curriculum should meet the demands of some emergent issues (Eyiuche Olibie) 


\section{METODE PELAKSANAAN}

Sasaran kegiatan pengabdian masyarakat ini adalah guru-guru PAUD di wilayah Kecamatan Tanah Abang Jakarta Pusat. Data dikumpulkan dengan cara menyebarkan kuesioner untuk mengetahui perubahan pemahaman dan kemampuan guru dalam menyusun RPPH, yang didukung pula dengan hasil penyusunan RPPH sebelum dan sesudah mendapatkan pelatihan. Analisa data dilakukan dengan menggunakan statistik sederhana, kemudian disajikan dalam bentuk grafik serta pemaparan bentuk deskriptif naratif.

Kegiatan pelatihan penyusunan rencana pelaksanaan pembelajaran harian ini dilakukan pada Rabu dan Kamis, 18 - 19 April 2018, yang berlokasi di RPTRA Intiland Teduh, Jakarta Pusat.

Adapun alat dan bahan yang digunakan untuk kegiatan pelatihan adalah kurikulum 2013 yang terdapat dalam Peraturan Menteri Pendidikan dan Kebudayaan Nomor 146 dan Nomor 137 Tahun 2014. Selain itu, juga digunakan berbagai media pembelajaran yang digunakan pada saat simulasi pembelajaran yang dilakukan oleh pemateri. Media pembelajaran juga disediakan untuk mendukung kegiatan simulasi perencanaan pembelajaran yang telah dibuat oleh peserta.

\section{Langkah Pelaksanaan}

Kegiatan dilakukan selama 2 hari dengan menggunakan metode penyampaian materi, workshop, simulasi dan pendampingan. Hari pertama, kegiatan diawali dengan penyebaran kuesioner untuk mengetahui pemahaman dan kemampuan guru dalam menyusun RPPH, yang kemudian dilanjutkan dengan penyampaian materi berupa 4 kompetensi Guru, kurikulum 2013, serta media pembelajaran. Adapun workshop dilakukan setelah penyampaian materi, dimana peserta diajak untuk menyusun perencanaan pembelajaran sesuai dengan apa yang biasa dilakukan guru di sekolah.

Kegiatan dilakukan dengan membahas hasil kerja peserta berupa penyusunan RPPH sebagaimana biasa dilakukan guru di sekolah, kemudian menjelaskan penyusunan RPPH berdasarkan kurikulum 2013. Kegiatan dilanjutkan dengan meminta peserta menyusun RPPH sesuai dengan materi yang telah diberikan dan berdasarkan pada kurikulum 2013. Setelah selesai, kegiatan selanjutnya adalah simulasi pembelajaran yang diberikan oleh pemateri. Peserta dilibatkan sebagai anak murid sehingga merasakan betul bagaimana pembelajaran yang diberikan.

Berikutnya, adalah kesempatan peserta untuk mensimulasikan RPPH yang telah direvisi. Peserta dibagi menjadi 4 kelompok besar, dengan peserta lain menjadi anak didiknya.

Kegiatan akhir adalah pemberian kuesioner, untuk mengetahui pemahaman dan kemampuan peserta setelah menerima rangkaian kegiatan pelatihan.

\section{HASIL DAN PEMBAHASAN}

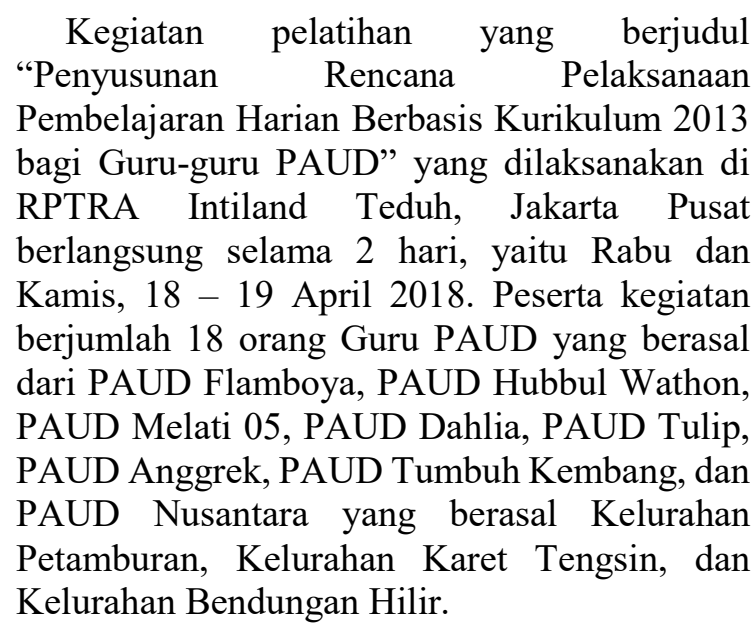

Kegiatan yang semula direncanakan akan dilaksanakan pukul 08.00 WIB, dimulai pada pukul 10.00 WIB. Hal ini dikarenakan permintaan guru-guru PAUD yang baru dapat mengikuti kegiatan pelatihan setelah kegiatan pembelajaran di PAUD selesai. Kegiatan pelatihan diawali dengan sambutan oleh ketua pelaksana kegiatan, ibu Rohita, M.Pd. yang menyampaikan mengenai tujuan dari kegiatan pelatihan yaitu untuk lebih mendekatkan kurikulum 2013 kepada guru-guru PAUD dan sekaligus menambah pemahaman mengenai kurikulum 2013 sehingga guru-guru PAUD dapat menggunakannya dalam menyusun rencana pelaksanaan pembelajaran harian (RPPH)." Sambutan berikutnya disampaikan oleh ibu Rida Mufida, SH., selaku sekertaris Lurah Karet Tengsin, Jakarta Pusat yang sekaligus membuka kegiatan pelatihan. Dalam kesempatan tersebut beliau menyampaikan bahwa "PG PAUD UAI telah melakukan kegiatan pembinaan untuk kali kedua. Yang pertama bagi guru-guru TK dan PAUD serta orangtua di sekitar Karet Tengsin dan yang kedua, ini bagi guru-guru PAUD. Semoga 
kegiatan yang diberikan menambah pengetahuan terutama dalam membuat perencanaan dan pembelajaran sesuai dengan kurikulum. Dan semoga ilmu yang diberikan dapat diimplementasikan dan dipraktekan di lingkungan PAUD kita sendiri."

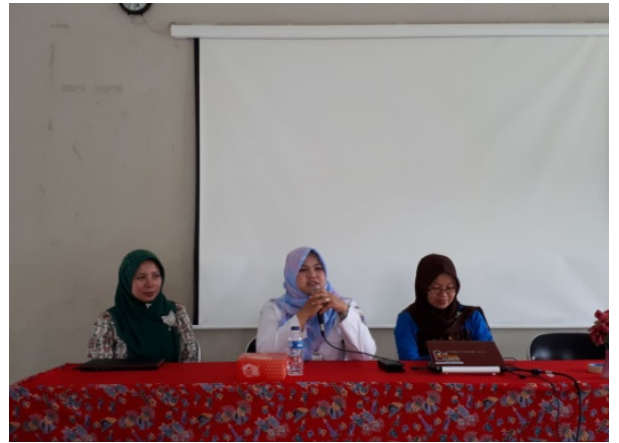

Gambar 2. Sambutan dan pembukaan kegiatan Pelatihan oleh Ibu Rida Mufidah, SH., sekertaris Lurah Karet Tengsin, Jakarta Pusat (kiri) dan foto bersama antara panitia, pemateri, peserta dan sekertaris lurah Karet Tengsin, Jakarta Pusat (kanan)

\section{a. Seminar}

Kegiatan dilanjutkan dengan Penyampaian materi oleh ibu Rohita, M.Pd., yang berjudul "Pentingnya Perencanaan Pembelajaran dan Dampaknya Bagi Tumbuh Kembang Anak". materi kedua disampaikan oleh ibu Nila Fitria, M.Pd. mengenai Perencanaan Pembelajaran yang Kreatif dan Efektif, diakhiri dengan tanya jawab.

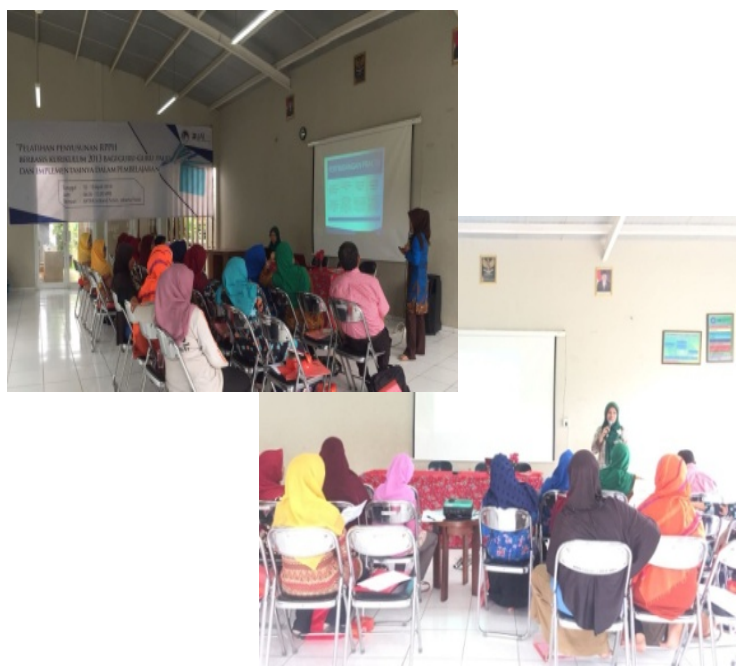

Gambar 3. Penyampaian Materi oleh Ibu Rohita, M.Pd. dan Ibu Nila Fitria, M.Pd.

Sebelum istirahat, peserta diminta untuk membuat RPPH sesuai dengan format yang biasa digunakan sebelum mendapatkan pelatihan. Peserta dibagi dalam dua kelompok besar, dimana masing-masing peserta membuat RPPH sendiri.

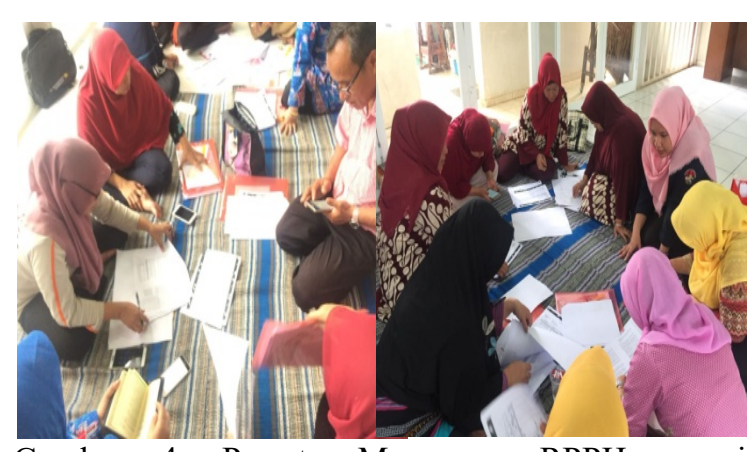

Gambar 4. Peserta Menyusun RPPH sesuai Pengetahuan dan Format yang Biasa digunakan di PAUD

Pada sesi kedua, yaitu pukul 13.00 kegiatan dilanjutkan dengan materi mengenai Penyusunan Rencana Pelaksanaan Pembelajaran Harian Berbasis Kurikulum 2013, yang disampaikan oleh Syarifah Nur Fadhila. Mahasiswa PG PAUD UAI tingkat akhir. Pada materinya, Syarifah menjelaskan mengenaipenyusunan RPPH menggunakan contoh yang telah dibuat sebelumnya, guna memudahkan guru-guru PAUD memahami penerapan kurikulum 2013 dalam RPPH.

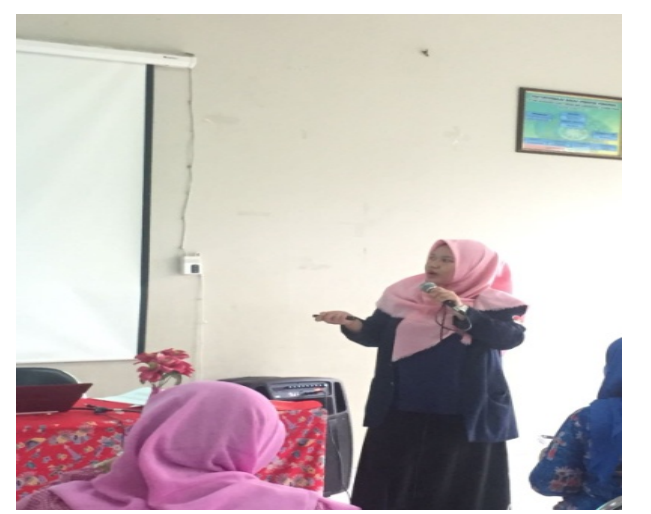

Gambar 5. Penyampaian materi oleh Syarifah Nur Fadhila

Setelah penyampaian materi selesai, kegiatan dilanjutkan dengan pembagian peserta menjadi 4 kelompok, untuk membuat RPPH menggunakan kurikulum 2013 sesuai dengan format yang diberikan.

\section{b. Pelatihan}

Hari kedua, Kamis, 19 April 2018, kegiatan pelatihan Penyusunan RPPH Berbasis Kurikulum 2013 Bagi Guru-Guru PAUD 
dilanjutkan. Kegiatan diawali dengan simulasi pembelajaran sesuai dengan RPPH berbasis kurikulum 2013 yang sebelumnya telah dicontohkan. Sebagian peserta dilibatkan sebagai anak didik dalam simulasi tersebut. Sementara sebagian peserta lainnya, diminta untuk memperhatikan simulasi yang akan dilakukan.

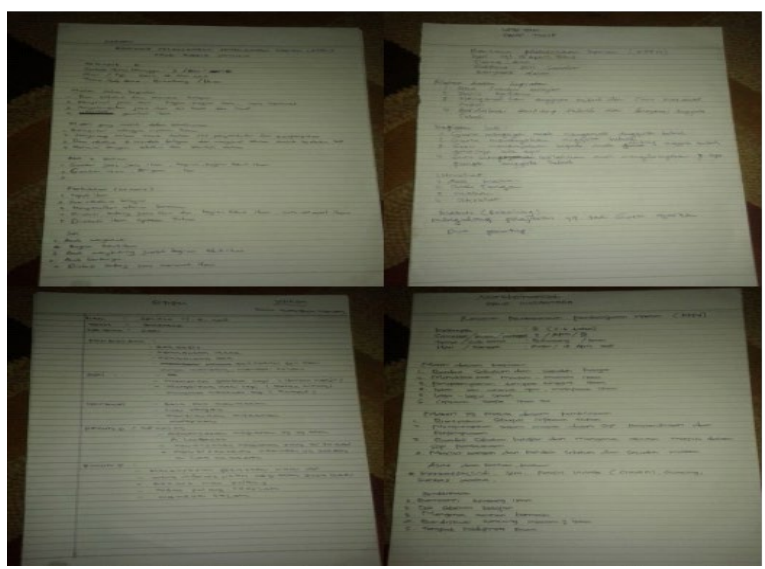

Gambar 6. Contoh RPPH Hasil Kerja Peserta Pelatihan

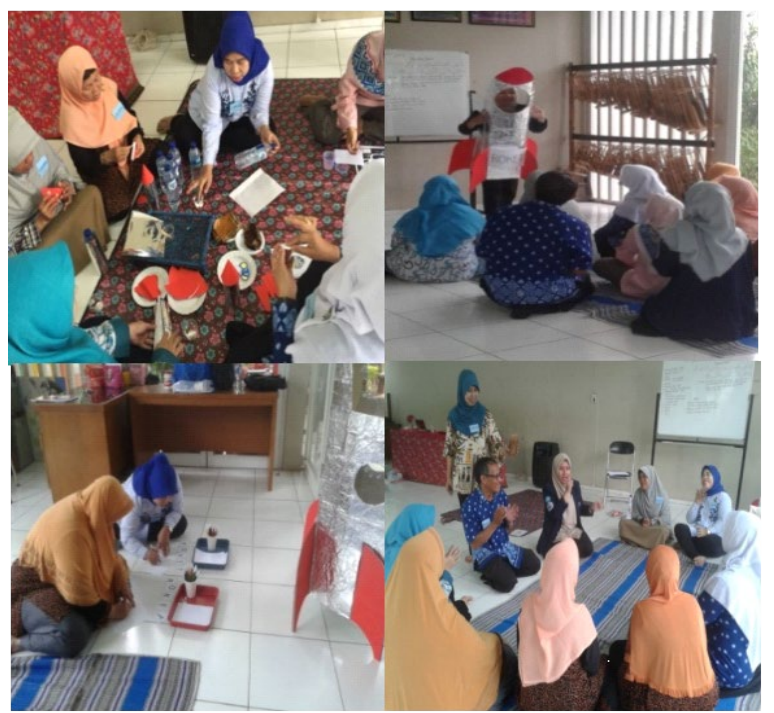

Gambar 7. Kegiatan Inti 1, 2, dan 3 dalam Simulasi Pembelajaran

Kegiatan selanjutnya, adalah simulasi yang dilakukan oleh 4 kelompok peserta pelatihan. Masing-masing kelompok mensimulasi kegiatan pembelajaran sesuai dengan RPPH yang telah disusun sebelumnya menggunakan berbagai media yang telah dipersiapkan dari rumah.

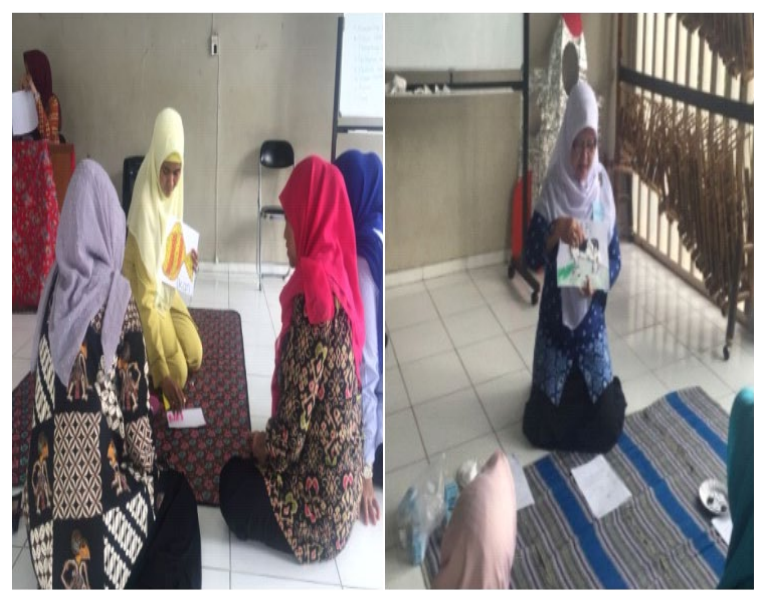

Gambar 8. Simulasi oleh kelompok 1 dengan Sub Tema "Ikan" (kiri) dan kelompok 2 dengan sub tema "Sapi" (kanan)

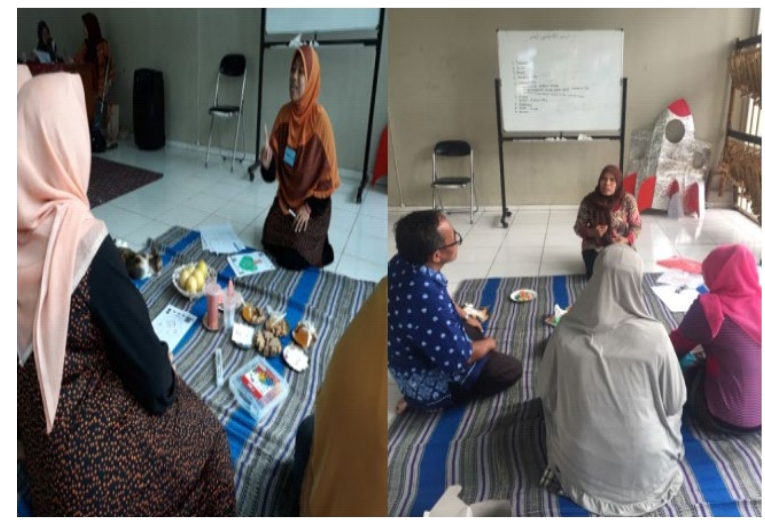

Gambar 9. Simulasi oleh kelompok 3 dengan sub tema "Jambu" (kiri) dan kelompok 4 dengan sub tema "Hamburger" (kanan)

Selesai simulasi pembelajaran, kegiatan dilanjutkan dengan evaluasi hasil simulasi pada setiap kelompok yang dilakukan oleh ibu Nila Fitria, M.Pd., dan Ibu Rohita, M.Pd.Evaluasi dilakukan berdasarkan hasil RPPH yang telah dibuat masing-masing kelompok serta berdasarkan hasil simulasi pembelajaran yang dilakukan sesuai dengan RPPH yang telah dibuat sebelumnya. Kegiatan terakhir adalah pengisian angket untuk mengetahui perubahan pemahaman dan kemampuan guru PAUD dalam menyusun RPPH berbasis Kurikulum 2013. 


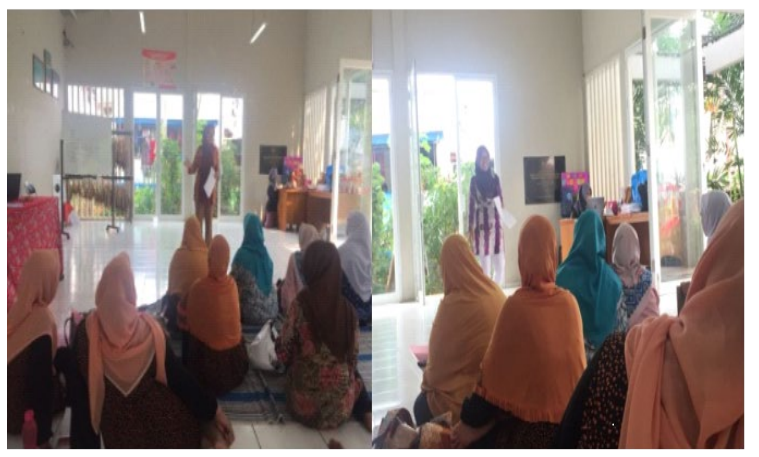

Gambar 10. Kegiatan Evaluasi dan Diskusi Hasil Simulasi Kegiatan Pembelajaran

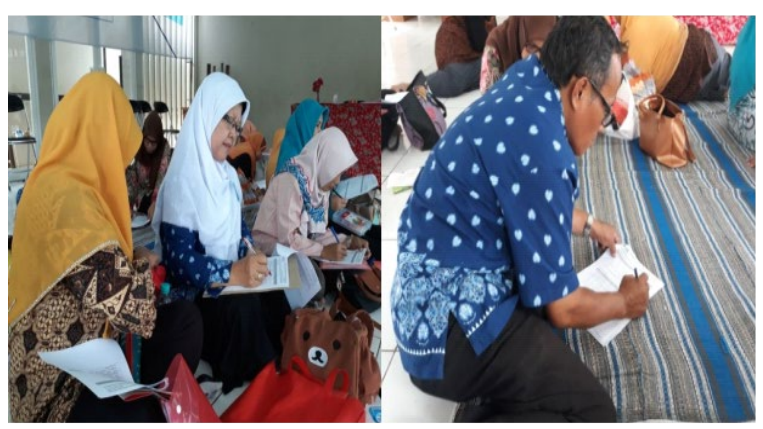

Gambar 11. Pengisian Angket oleh Peserta Kegiatan Pelatihan

Berdasarkan hasil angket diketahui tingkat pendidikan dan lama bekerja guru-guru PAUD di Kecamatan Tanah Abang, yang disajikan pada grafik di bawah.

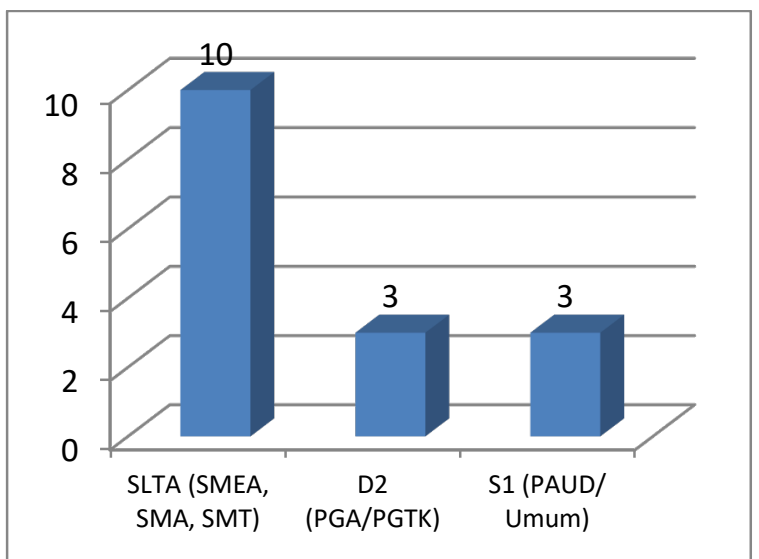

Gambar 12. Data Latar Belakang Pendidikan Guru PAUD di Kecamatan Tanah Abang

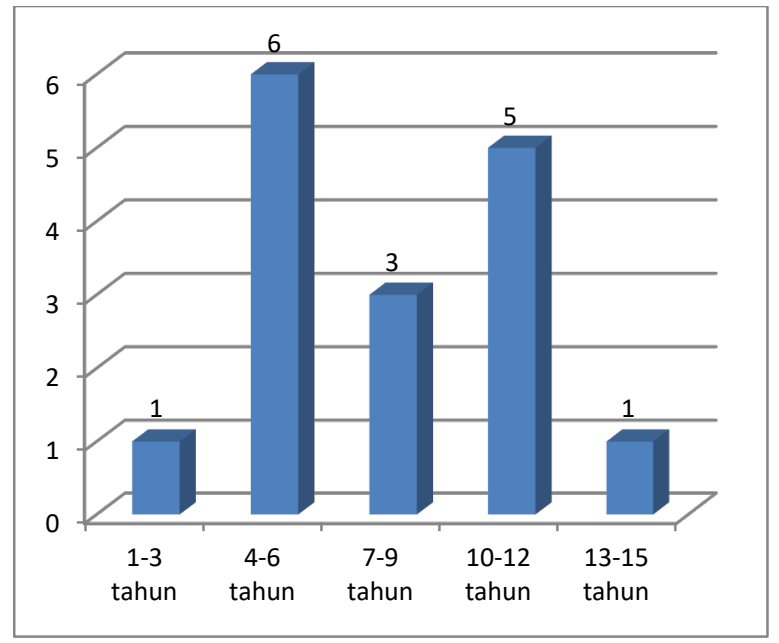

Gambar 13. Data Lama Bekerja Guru PAUD di Kecamatan Tanah Abang

Berdasarkan Gambar 12 dan Gambar 13, diketahui bahwa $62.50 \%$ guru-guru PAUD berlatar belakang pendidikan SLTA yang meliputi SMEA, SMA, dan SMT; 18.75\% berlatar belakang pendidikan D2 (PGA dan PGTK); serta $18.75 \%$ berlatar belakang pendidikan S1 (PAUD dan ekonomi). Dilihat dari lamanya bekerja guru-guru PAUD, terbanyak adalah sekitar 4-6 tahun yaitu $37.50 \%$; 10-12 tahun sebanyak $31.25 \%$; 7-9 tahun sebanyak $18.75 \%$; serta $1-3$ tahun dan $13-$ 15 tahun sebanyak 6.25\%. Dari kedua data tersebut dapat dikatakan bahwa banyak guruguru PAUD utamanya yang mengajar di wilayah Kecamatan Tanah Abang memiliki latar belakang pendidikan SLTA dengan lama bekerja rata-rata 4 sampai 12 tahun. Hal tersebut berdampak pula pada pengetahuan dan kemampuan guru-guru PAUD di wilayah tersebut dalam kaitannya dengan penyusunan RPPH.

Berdasarkan kuesioner yang diberikan diketahui bahwa peserta kegiatan pelatihan Penyusunan Rencana Pelaksanaan Pembelajaran Harian Berbasis Kurikulum 2013 bagi Guru-Guru PAUD yang berjumlah 18 orang menyatakan bahwa pelatihan yang diberikan membantu guru-guru PAUD memahami lebih dalam mengenai kurikulum 2013 serta cara menyusun RPPH menggunakan kurikulum 2013 tersebut. 
Berikut juga disajikan data pengetahuan dan kemampuan guru-guru PAUD pesertapelatihan antara sebelum dan sesudan pelatihan.

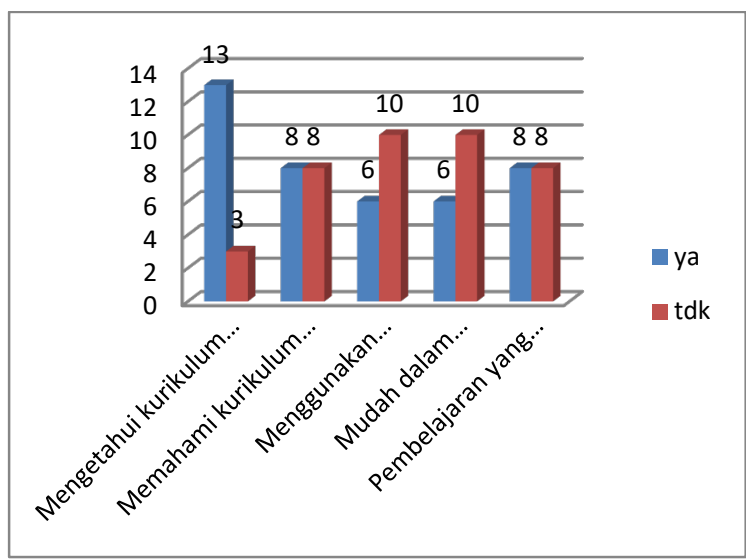

Gambar 14. Data Sebelum Pelatihan

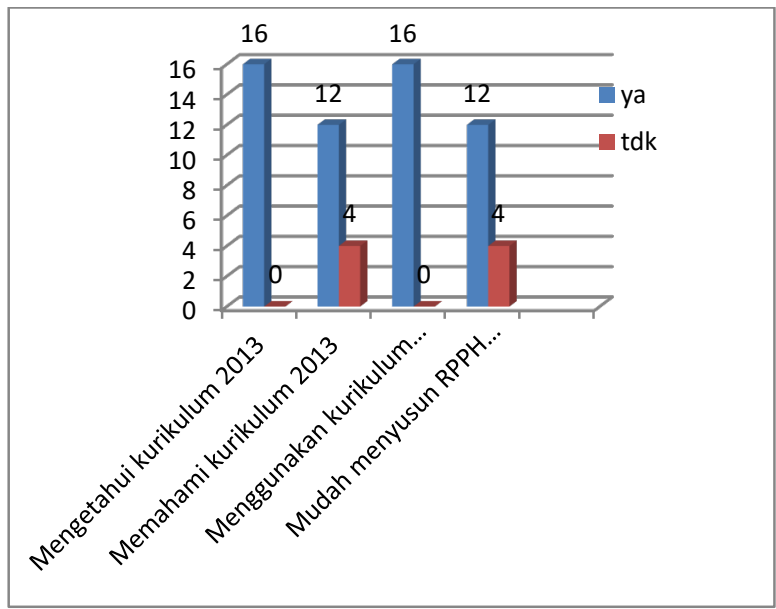

Gambar 15. Data Sesudah Pelatihan

Terkait tingkat pengetahuan guru PAUD mengenai kurikulum 2013 sebelum pelatihan diketahui bahwa $81.25 \%$ guru telah mengetahui kurikulum 2013; 50\% guru telah memahami kurikulum 2013; 37.50\% guru menggunakan kurikulum 2013 dalam menyusun RPPH; $37.50 \%$ guru menyatakan mudah dalam menyusun RPPH menggunakan kurikulum 2013; dan 50\% guru menyatakan bahwa pembelajaran yang diberikan telah sesuai RPPH yang dibuat. Kemudian, dari data sesudah pelatihan diketahui bahwa $100 \%$ guru telah mengetahui kurikulum 2013; 75\% menyatakan memahami kurikulum 2013; $100 \%$ menggunakan kurikulum 2013 dalam menyusun $\mathrm{RPPH} ; 75 \%$ mudah menyusun $\mathrm{RPPH}$ menggunakan kurikulum 2013. Adanya data sebelum dan sesudah pelatihan menunjukkan bahwa terdapat peningkatan pengetahuan guruguru PAUD mengenai kurikulum 2013 yaitu sebesar $18.75 \%$; peningkatan pemahaman sebesar 25\%; peningkatan penggunaan kurikulum 2013 dalam menyusun RPPH sebesar $62.50 \%$; dan peningkatan kemampuan menyusun RPPH menggunakan kurikulum 2013 sebesar $37.50 \%$.

Sementara berdasarkan hasil penyusunan RPPH peserta pelatihan sebelum pelatihan diperoleh informasi yang disajikan pada grafik berikut ini.

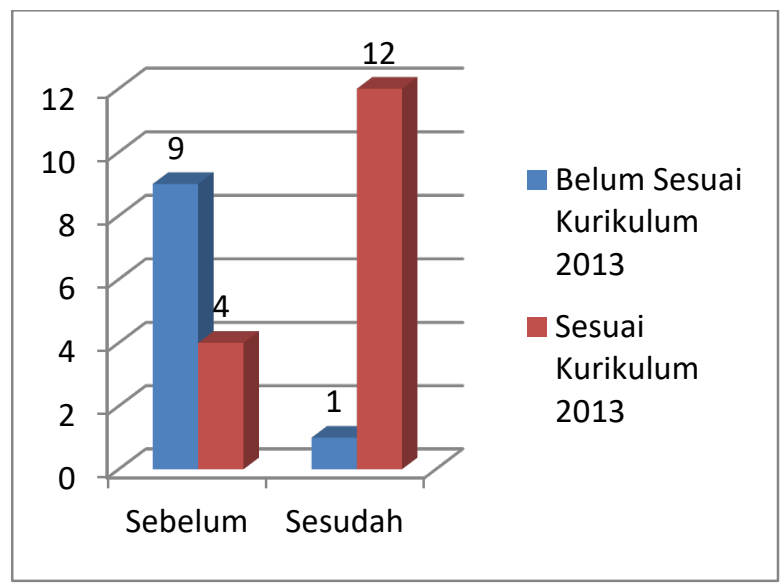

Gambar 16. Data Hasil Penyusunan RPPH Peserta Sebelum Pelatihan

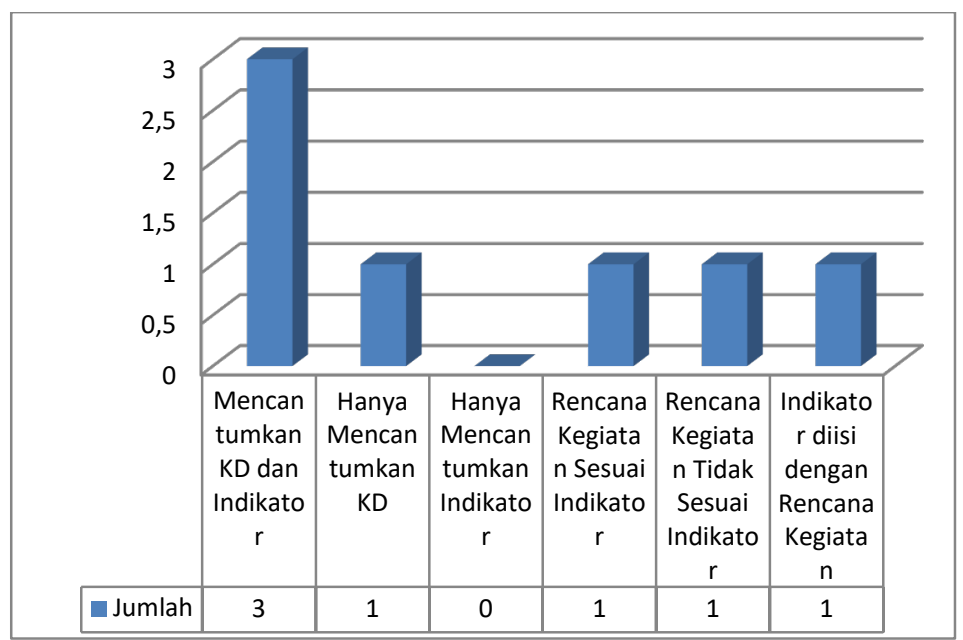

Gambar 17.Konten RPPH Hasil Pelatihan

Berdasarkan hasil penyusunan RPPH peserta yang dibandingkan dengan hasil RPPH sesuai juknis Penyusunan RPPH berbasis kurikulum 2013 diketahui bahwa sebelum pelatihan 75\% RPPH peserta belum sesuai kurikulum 2013; dan 25\% telah sesuai kurikulum 2013. Sementara RPPH yang dibuat sesudah pelatihan menunjukkan adanya kesesuaian antara RPPH peserta pelatihan dengan RPPH dalam Juknis Penyusunan RPPH berbasis kurikulum 2013. Namun dalam pelaksanaannya, guru-guru PAUD belum mampu menghadirkan media sesungguhnya atau bentuk tiga dimensi dalam 
proses penyampaian materi. Media yang digunakan masih sebatas pada gambar dua dimensi. Pada kegiatan inti, kegiatan-kegiatan yang diberikan kurang variatif dan cenderung menggunakan paper and pencil, sebagai contoh menghitung gambar kaki sapi, menempel kapas pada gambar sapi membentuk warna kulit sapi, dan menempel kartu huruf membentuk kata sapi.

Adapula kelompok yang membahas sub tema "jambu", dengan menjelaskan pula tentang "jamu" di dalam penyampaian materinya. Hal tersebut menunjukkan bahwa guru belum mampu menyampaikan materi sesuai dengan tema dan sub tema yang telah dipilih. Kelompok dengan sub tema "ikan" belum menghadirkan "ikan sesungguhnya" untuk memahamkan anak mengenai materi tentang ikan. Guru hanya menggunakan bentuk dua dimensi sehingga anak tidak dapat memahami "ikan" lebih banyak. Kelompok terakhir, memilih sub tema "hamburger" dimana dalam penyampaian materinya, guru belum mampu menjelaskan secara rinci apa itu "hamburger", "manfaatnya", serta berbagai hal terkait "hamburger".

Namun guru-guru PAUD telah mensimulasikan pembelajaran sesuai dengan RPPH yang telah dibuat sebelumnya. Adanya perencanaan pembelajaran tentu akan memberikan berbagai informasi mengenai berbagai kegiatan yang telah dilakukan guruguru PAUD. Dengan adanya perencanaan, guru dapat mengetahui apakah kegiatan yang diberikan telah sesuai dengan pedoman atau panduan, apakah kegiatan yang diberikan dapat menggambarkan hasil yang diharapkan, apakah kegiatan yang diberikan sesuai dengan perencanaan yang telah dibuat, dan apakah kegiatan yang telah diberikan dapat dijadikan alat evaluasi.

\section{SIMPULAN DAN SARAN}

\section{Simpulan}

Kesimpulan dari kegiatan pelatihan yang berjudul Penyusunan RPPH Bagi Guru-Guru PAUD Berbasis Kurikulum 2013 ini adalah adanya peningkatan pemahaman guru-guru PAUD dalam menyusun RPPH Berbasis Kurikulum yaitu sebesar 25\%, dan peningkatan kemampuan guru-guru PAUD dalam menyusun RPPH Berbasis Kurikulum sebesar 37.50\%.
Peningkatan pemahaman dan kemampuan guru-guru PAUD dalam menyusun RPPH berbasis Kurikulum 2013 ini dapat dilihat dari RPPH hasil kerja guru baik berupa RPPH maupun konten yang dibandingkan dengan RPPH yang terdapat pada buku Petunjuk Teknis Penyusunan RPPH. Hal tersebut juga menjadi indikator keberhasilan kegiatan pelatihan dimana terjadi peningkatan sebesar $66.6 \%$.

Implikasi pelatihan ini adalah guru-guru PAUD khususnya di wilayah Jakarta Pusat, akan dapat menyusun RPPH sebagaimana seharusnya sehingga memudahkan guru-guru PAUD itu sendiri dalam memberikan pembelajaran kepada anak didiknya. Dengan adanya RPPH guru memiliki arah dan urutan kegiatan yang akan diberikan kepada anak, yang tentunya juga sesuai dengan Tema dan Sub Tema yang akan dibahas pada hari itu. Kesesuaian kegiatan dengan Tema dan Sub Tema menjadi penting agar anak memiliki pemahaman dan kemampuan yang utuh mengenai apa yang anak dengarkan dengan apa yang anak lakukan.

Urutan yang jelas juga melatih hidup dan kemampuan berpikir anak akan urutan yang harus dilakukan. Anak menjadi terbiasa dengan aturan-aturan atau kegiatan-kegiatan yang akan dilakukan berikutnya setelah kegiatan yang satu selesai. Hal ini dapat membantu anak menyiapkan diri untuk menerima tugas berikutnya.

Adanya kemampuan menyusun RPPH, yang sesuai dengan Petunjuk Teknis juga memudahkan guru dalam melakukan evaluasi, baik evaluasi terhadap kesesuaian pembelajaran dengan kurikulum 2013, maupun evaluasi kemampuan yang dicapai anak setelah melakukan kegiatan pembelajaran. Berdasarkan hasil evaluasi, guru dapat mengetahui efektifitas kegiatan yang diberikan kepada anak, serta keterlaksanaannya. Apakah kegiatan tersebut menarik minat anak, dapat meningkatkan keterampilan anak, atau yang lainnya. Hasil evaluasi yang didasarkan dari RPPH tersebut juga dapat membantu guru mengetahui bagaimana peningkatan pengetahuan dan kemampuan anak, yang selanjutnya dapat digunakan untuk menentukan kegiatan apa yang harus diberikan kepada anak untuk meningkatkan pengetahuan ataupun kemampuannya tersebut. 


\section{Saran}

Adapun saran yang dapat diberikan adalah pertama, guru-guru PAUD perlu lebih memahami kegiatan-kegiatan yang akan diberikan sesuai dengan KD dan indikator yang dipilih; kedua, Guru-guru PAUD perlu lebih variatif dalam memberikan kegiatan kepada anak didiknya, tidak hanya kegiatan yang menekankan kepada kemampuan kognitif dan motorik halus, tetapi juga kegiatan yang melatih keterampilan dan seni anak, juga kognitif yang mengarah pada peningkatan daya pikir anak; ketiga, guru-guru PAUD perlu menyiapkan media yang lebih konkrit sebagai alat bantu dalam penyampaian materi di awal kegiatan; keempat, perlunya penelitian lebih lanjut mengenai analisa kegiatan pembelajaran dalam RPPH; dan, kelima,perlunya pelatihan lanjutan mengenai pembuatan media appersepsi 3D serta penyusunan variasi kegiatan berbasis tema.

\section{UCAPAN TERIMAKASIH}

Ucapan terimakasih kami sampaikan kepada Lembaga Penelitian dan Pengabdian Masyarakat (LP2M) Universitas Al Azhar Indonesia yang telah memberikan dukungan dana serta berbagai fasilitas guna memperlancar kegiatan pengabdian kepada masyarakat ini.

\section{DAFTAR PUSTAKA}

Metina, M. (2013). Teachers' Difficulties in Preparation and Implementation of Performance Task. Educational Sciences: Theory \& Practice. 13(3) • 1664-1673 DOI: 10.12738/estp.2013.3.1452

Ntumi, S. (2016). Challenges Pre-School Teachers Face in the Implementation of the Early Childhood Curriculum in the Cape
Coast Metropolis. Journal of Education and Practice, ISSN 2222-1735 (Paper) ISSN 2222-288X (Online). Vol.7, No.1, p. 54-62.

Olibie, E. (2013). Emergent Global Curriculum Trends: Implications for Teachers as Facilitators of Curriculum Change. Journal of Education and Practice. ISSN 2222-1735. ISSN 2222-288X (Online) Vol.4, No.5, 2013, p. $161-167$.

Rohita; Fitria, Nila; Haryadi, Dody. (2018). Pemanfaatan Aplikasi Penyusunan Perencanaan Pembelajaran (AP3) dalam Penyusunan Perencanaan Pembelajaran bagi Guru Taman Kanak-Kanak di Jakarta. JPKM Jurnal Pengabdian kepada Masyarakat. Vol. 24, No. 2, April-Juni 2018. Hal. 648-654.

Selvi, K. (2010). Teachers' Competencies. Faculty of Education. Anadolu University, 26470 Eskisehir, Turkey. Vol VII, No. 1

Kementerian Pendidikan dan Kebudayaan RI. (2015). Buku Penyusunan Rencana Pelaksanaan Pembelajaran Pendidikan Anak Usia Dini. Jakarta : DirjendPAUDDIKMAS, 2015

Kementerian Pendidikan dan Kebudayaan RI. (2013). Peraturan Menteri Pendidikan dan Kebudayaan No 81A tahun 2013 tentang implementasi Kurikulum Pedoman Umum Pembelajaran.

Kementerian Pendidikan dan Kebudayaan RI. (2014). Peraturan Menteri Pendidikan dan Kebudayaan Republik Indonesia Nomor 146 Tahun 2014 tentang Kurikulum 2013 Pendidikan Anak Usia Dini

Kementerian Pendidikan dan Kebudayaan RI. (2003). UU No. 20 Tahun 2003 tentang Sistem Pendidikan Nasional 